\title{
Determinant of net interest income of commercial banks in Indonesia
}

\section{R. Mahelan Prabantarikso ${ }^{a}$, Zaenal Abidin ${ }^{b^{*}}$, Edian Fahmy $^{\mathrm{c}}$, Mayda Tyastika ${ }^{\mathrm{d}}$ and Amabel Nabila $^{\mathrm{e}}$}

\section{H R O N I C L E}

\begin{tabular}{l}
\hline Article history: \\
Received September 26, 2021 \\
Received in revised format \\
October 102021 \\
Accepted December 202021 \\
Available online \\
January 182022 \\
\hline Keywords: \\
Net interest income (NII) \\
Commercial Banks \\
Credit \\
NPL \\
Vector Error Correction Model
\end{tabular}

a Assistant Professor, Sekolah Tinggi Ilmu Ekonomi Indonesia Banking School, Jakarta, 12730, Indonesia

${ }^{b}$ Associate Professor, Perbanas Institute, Jakarta, 12940, Indonesia

${ }^{c}$ Universitas Pamulang, Tangerang Selaran, Banten, Indonesia

${ }^{d}$ Assistant Professor, Perbanas Institute, Jakarta, 12940, Indonesia

eAssistant Lecturer, Universitas Brawijaya, Malang, 65145, Indonesia

\section{A B S T R A C T}

\begin{abstract}
This study aims to identify the factors that contribute to the formation of Net interest income (NII) for commercial banks in Indonesia in the short and long-term using the Vector Error Correction Model (VECM). The results showed that in the short term all variables in each period tend to adjust to achieve long-term balance. In the short term, the variables that affect NII are credit and NPL of large and retail trade, construction credit, transportation credit and NPL warehousing and communication, as well as lending rate facility. While in the variable length figures that affect NII are credit variables and NPL large and retail trade, Credit and NPL Transportation, warehousing and communication, other credit and Third-Party Funds (Deposit) collected. The analysis of Impulse Response Function can be proven that NII most quickly achieves stability when dealing with the shocks of large trade and retail NPL. Meanwhile, in the Forecasting Variance Decomposition analysis, it can be concluded that the variable that gives the greatest contribution to NII is the amount of construction credit.
\end{abstract}

(C) 2022 Growing Science Ltd. All rights reserved.

\section{Introduction}

The banking industry in Indonesia continues to experience growth, seen from the value of its total assets, banking in Indonesia recorded a growth of $63 \%$ from Rp5,031 trillion in 2013 to Rp8,204 trillion as of December 2018. Meanwhile, when viewed from the source of funds (deposit) collected, Indonesian banks recorded a rapid growth of funds of $59 \%$ from Rp4,134 trillion in 2013 to Rp 6,586 trillion as of December 2018. The growth in the source of funds was also followed by the growth of the amount of credit disbursed from Rp 4,897 trillion in 2013 to Rp 7,939 trillion per December 2018 or grew $62 \%$ (Bank of Indonesia, 2018). Judging from the credit growth, the construction sector recorded the highest credit growth of $22.08 \%$ (yoy), in line with the rampant infrastructure development in various regions. The mining and quarrying sector also recorded high growth of $21.38 \%$ (yoy). Furthermore, the transportation, warehousing and communication sectors also grew high by $20.37 \%$ (yoy), primarily supported by an increase in credit in the telecommunications services subsector which grew $44.60 \%$ (yoy). Large trade and retail sector credit which is the bank's flagship sector in channeling its credit (18.43\%) also recorded significant growth of $10.23 \%$ (yoy), higher than the previous year which only grew 5.24\% (yoy).

Some previous studies have found that economic conditions and monetary policies for the economy will also have an impact on the profitability of banks or better known as Net Interest Income (NII). Among them is Kumar et al. (2020), Prasanto et al. (2020), Yüksel et al. (2018), and Zimmermann (2017). Macro prudential factors such as lending rate can affect bank profitability (Kumaran \& Ismail, 2018; Mukolu \& Adeleke, 2020; Syamni \& Musnadi, Said Faisal, 2017) and micro prudential factors such as bad credit (NPL) (Tan \& Floros, 2012).

* Corresponding author.

E-mail address: zaenal@perbanas.id (Z. Abidin) 
At the same time Borio et al. (2017) conducted research on how monetary policy affects bank profitability. The research was conducted on 109 International Banks headquartered in 14 developed countries for the period 1995-2012. The study found a positive link between the structure of interest rates and the profitability of banks. A subsequent study of Bikker and Vervliet (2018) that sampled banking in America found that low interest rates can certainly damage bank performance and depress bank margins. Then Kohlscheen et al. (2018) found that long-term interest rates tend to increase profitability. Research on the contribution of NII formation continues to grow and becomes an interesting topic to research in Indonesian Banking because there is a tendency to decrease NII. Currently there are a lot of research on the contribution of NII in Indonesia but very limited that includes all kinds of variables that affect NII such as the use of lending rate (macro prudential) and five types of credit and NPL as well as banking deposits or better known as micro prudential. This study aims to identify the factors that contribute to the formation of NII for Commercial Banks in Indonesia in the short and long term. The specific objectives of this study are further detailed through the analysis of the factors of the macro prudential and micro prudential variables on the NII of Commercial Banks in Indonesia if a variable experiences shocks and forecasts in the future.

\section{Literature Review}

Lamb et al. (2013) aimed to analyze the bank's products that contributed to the formation of the largest profit. The study used net profit as a dependent variable and as an independent variable among them were Commercial Loans; Agriculture Loans; Agriculture Operating Loans; Commercial Op Loans; Total Commercial Deposits; Agriculture Real Estate; Consumer Real Estate; Consumer Other Loans; and Equity are categorized as micro prudential factors while Gross Domestic Product, EC Unemployment rate is categorized as macro prudential. The results obtained from the study include Commercial loans, deposits and changes in consumer real estate have a significant positive effect on profit formation. The results of their next study mentioned that total securities, commercial real estate, and agriculture real estate have a significant negative effect on profit formation. The results of the study mentioned that commercial term notes have no significant effect on profit. As for other variables that are not mentioned, described has no effect on profit because it is affected by multicollinearity. Similar research was conducted by Duraj and Moci (2015) with slightly different analysis results. The difference in the results of the study lies in credit variables that negatively affect bank profits, while in Lamb et al. (2013) it is explained that not every sector given credit distribution has a negative influence on profit. Duraj and Moci's research (2015) also explained about NPL variables that have no effect on ROE because the NPL value is very high. Variable inflation is described as having a significant negative effect on ROE. Deposit and GDP variables are described to have a significant positive effect on ROE. Vejzagig and Zarafat (2014) which uses data ranging from 1995-20111 and aims to analyze the influence of macroeconomic factors on commercial bank profits in Malaysia. The ROA variable is selected to be a dependent variable. Variable Real Interest Rate; Consumer Price Index; Real GDP is chosen to be an independent variable. The results of the first study showed that Real GDP has a significant positive effect on banking profits in Malaysia. Both Real Interest Rates have no effect on banking profits in Malaysia. The three CPI have no significant negative effect on Maybank but are significant to Public Bank and Bank Leong.

Javaid et al. (2011) aims to analyze internal factors that affect bank profits in Pakistan. They used ROA variables as dependent variables while representing profit and deposit variables, total credit, total assets, and total equity as independent variables. The results explain that the variable total deposit and equity will have a significant positive effect on bank profits in Pakistan. Variable total assets have a significant negative impact on bank profits in Pakistan. As for the total variable, credit channeled will contribute to the bank's profit getting bigger if the distribution is getting bigger, but the effect is not significant. Alper and Anbar's research (2011) aims to analyze the factors that affect the profits of Commercial Banks in Turkey in terms of macroeconomics and banking specifications. The study used variable amounts of credit, deposit, real interest rates, total assets, GDP and inflation as independent variables and ROA and ROE as dependent variables. The results explain that total credit and assets have a significant negative effect on ROA and ROE and real interest rates have a positive effect on ROA and ROE. Dezfouli et al. (2014) generally aimed to identify the bank's profit from the effectiveness of liquidity management. The research, among others, explains one of the factors that is NPL that can erode profit if NPL increases. The interesting thing about their research is the importance of a bank maintaining its liquidity through increasing the amount of deposit. Attention to the high GDP contributing sector is also important as it relates to expectations of future returns. Almazari's research (2014) aims to compare the factors that affect profits from internal banks in Saudi and in Jordan. The study explained that profits at Saudi banks tend to be influenced by equity, deposit, and investment. The bank's profit in Jordania tends to be influenced by total credit, deposit, and equity. The research became interesting because it turns out that the factors that affect profit can be different in different countries. Total credit channeled by banks in Jordan affects profit because the quality of the credit provided is relatively good. This shows that the bank's ability in Jordan in managing its product assets in the form of credit has been effective. According to Haddawe and Flayyih (2020) deposit has a significant influence on profitability indicators. Savings became the largest deposit that contributed to profitability followed by deposits and current accounts that contributed the least in profitability.

Borio et al. (2015) conducted research on how monetary policy affects bank profitability. The research was conducted on 109 International Banks headquartered in 14 developed countries for the period 1995-2012. The study found a positive link between the structure of interest rates and the profitability of banks. On the one hand, short-term interest rates and the tilt 
of the yield curve are positively linked to the bank's net interest income. On the other hand, higher interest rates increase loan cost losses, are consistent with their impact on borrowing costs and possible defaults and depress non-interest income. They also found that the impact of interest rates on bank profitability is huge when interest rates are low. Therefore, the purpose of this research is to investigate the elements that influence the establishment of NII for commercial banks in Indonesia in the short and long term. The aims of this study are further defined through an examination of the effects of macroprudential and macroprudential variables on the NII of Indonesian commercial banks if a variable suffers shocks and forecasts in the future.

\section{Methods}

\subsection{Research variables}

The variables used in this study were categorized into two categories namely dependent and independent variables. Determination of dependent and independent variable types refers to Lamb (2013). The dependent variable in this study was Net Interest Income (NII). NII is an indicator used to determine the bank's ability to manage its productive assets to generate net profit. Independent variables in this study include factors-factors that affect NII Commercial Banks in Indonesia are:

1. Total loans distributed to 5 sectors of the economy from Commercial Banks in Indonesia

2. NPL for 5 economic sectors of Commercial Banks in Indonesia

3. Deposit amount collected by Commercial Banks in Indonesia

4. Lending rate facility

\subsection{Research object}

The population in this study is financial institutions then since commercial banks are part of financial institutions. The sample of this study is Commercial Banks in Indonesia. Commercial Banks in Indonesia were chosen as samples because to better represent the actual conditions that occur in the scope of Indonesian banks. The data is time series with monthly intervals with a period from January 2015 to March 2019.

\section{Analytical tools}

This study used vector error correction model (VECM) data analysis tool. VECM is the restricted VAR model that can be used to see relationships between nonstationary variables but has the potential to be integrated. Integration is a linear combination of non stational variables, where there is a potential for long-term relationships. Short-term relationships can be obtained through the error correction model. The co-integration equation will be incorporated into the model after cointegration testing on the model used (Firdaus, 2011). Most time series data have a stationary level of first difference or I (1). VECM will be used if the data obtained has a stationary degree I (1) in anticipation of loss of information. The analytical tool model used in this study is almost like Al-Tamimi (2010), and Lamb (2013) as follows:

$$
\begin{aligned}
& \Delta \text { NIIt }=\alpha_{1}+\alpha_{\text {NII }}^{\mathrm{e}} \mathrm{t}-1+\sum_{\mathrm{i}=1}^{\mathrm{p}} \alpha_{11} \text { (i) } \Delta \text { NIIt-1 }+\sum_{\mathrm{i}=1}^{\mathrm{p}} \alpha_{13} \text { (i) } \Delta \text { CMiningt- } 1+\sum_{\mathrm{i}=1}^{\mathrm{p}} \alpha_{15} \text { (i) } \Delta \text { CTradingt-1 } \\
& +\sum_{\mathrm{i}=1}^{\mathrm{p}} \alpha_{17} \text { (i) } \Delta \text { Constructiont- } 1+\sum_{\mathrm{i}=1}^{\mathrm{p}} \alpha_{18} \text { (i) } \Delta \text { Transportt- } 1+\sum_{\mathrm{i}=1}^{\mathrm{p}} \alpha_{19} \text { (i) } \Delta \text { Othert-1 } \\
& +\sum_{\mathrm{i}=1}^{\mathrm{p}} \alpha_{21}(\mathrm{i}) \Delta \text { NPLMiningt-1+ } \sum_{\mathrm{i}=1}^{\mathrm{p}} \alpha_{21} \text { (i) } \Delta \text { NPLTrading- } 1+\sum_{\mathrm{i}=1}^{\mathrm{p}} \alpha_{21}(\mathrm{i}) \Delta \text { NPLConstructiont-1 } \\
& +\sum_{\mathrm{i}=1}^{\mathrm{p}} \alpha_{20}(\mathrm{i}) \Delta \text { NPLTransportt-1 }+\sum_{\mathrm{i}=1}^{\mathrm{p}} \alpha_{21}(\mathrm{i}) \Delta \text { NPLOthert-1 }+\sum_{\mathrm{i}=1}^{\mathrm{p}} \alpha_{22}(\mathrm{i}) \Delta \text { Deposit-1 } \\
& +\sum_{\mathrm{i}=1}^{\mathrm{p}} \alpha_{23}(\mathrm{i}) \Delta \text { LendingRate }+\varepsilon_{\mathrm{kp}}
\end{aligned}
$$

Information:

Mining (mining and quarrying credits); Trade credits, large and retail); Construction (construction credit); Transportation (transportation credit, warehousing and communication); Klainnya (other credit), and to; NPL Mining (mining and quarrying); NPL Trade (trade, large and retail; NPL construction (construction); NPL Transportation (transportation, warehousing and communication); Other NPL (other loans), deposit (third party funds), Lending rate (Lending rate facility) and NII (Net Interest Income).

\section{Results and Discussion}

\subsection{Unit root test results}

Before performing a time series analysis, it should test the stationarity of the data. Test data stationarity using Dickey Fuller Augmented Test (ADF). The hypotheses that underlie data stationarity testing are:

$\mathrm{H}_{0}: \delta=0$ (data is not stationary)

$\mathrm{H}_{1}: \delta \neq 0$ (data is stationary)

Here are the results of the data stationarity of one endogenous variable and 12 ex-eigenvariables. 
Table 1

Data Stationary Results

\begin{tabular}{|c|c|c|c|c|}
\hline \multirow{2}{*}{ variable } & \multicolumn{2}{|c|}{ Stationary test at the } & \multicolumn{2}{|c|}{ Stationary test on first difference } \\
\hline & Probabilities ADF & information & Probabilities ADF & information \\
\hline NII & 0.0008 & Stationary & $0.0001^{*}$ & Stationary \\
\hline Mining and quarrying credits & 0.3551 & Not stationary & $0.0000^{*}$ & Stationary \\
\hline Large trade and retail credits & 0.1002 & Not stationary & $0.0000 *$ & Stationary \\
\hline Construction Credits & 0.2169 & Not stationary & $0.0000 *$ & Stationary \\
\hline Transportation credits, warehousing, and communication & 0.8535 & Not stationary & $0.0000^{*}$ & Stationary \\
\hline Other Credits & 0.0015 & Stationary & $0.0005^{*}$ & Stationary \\
\hline NPL mining and quarrying & 0.7824 & Not stationary & $0.0000^{*}$ & Stationary \\
\hline NPL large trade and retail & 0.4945 & Not stationary & $0.0000 *$ & Stationary \\
\hline NPL Construction & 0.1435 & Not stationary & $0.0000^{*}$ & Stationary \\
\hline NPL Transportation, warehousing, and communication & 0.7226 & Not stationary & $0.0000^{*}$ & Stationary \\
\hline Other NPL & 0.7076 & Not stationary & $0.0000^{*}$ & Stationary \\
\hline Lending Facility & 0.4986 & Not stationary & $0.0000^{*}$ & Stationary \\
\hline Deposit & 0.0968 & Not stationary & $0.0000^{*}$ & Stationary \\
\hline
\end{tabular}

Based on Table 1 after all variables became stationary after performing the first difference $(\alpha=0,05)$ and it can be interpreted that all variables are stationary in the first differentiation. Therefore, integrated first order or I (1).

\section{Cointegration test}

Based on the cointegration test using Johansen, the results show that at lag 1 the value of trace statistics and maximum eigenvalue at $r=1$ is greater than the critical value with a significance level of $5 \%$. This means that the null hypothesis which states that there is no cointegration is rejected and the alternative hypothesis which states that there is cointegration that cannot be rejected. So that among the twelve variables in this study, there is at least one cointegration at the $5 \%$ significance level.

Table 2

Number of Integrated Equations

\begin{tabular}{|c|c|c|c|c|}
\hline $\begin{array}{l}\text { Hypothesized } \\
\text { No. of CE(s) }\end{array}$ & Eigenvalue & $\begin{array}{c}\text { Trace } \\
\text { Statistic }\end{array}$ & $\begin{array}{c}0.05 \\
\text { Critical Value }\end{array}$ & Prob.** \\
\hline None & 0.934891 & 608.1809 & on & on \\
\hline At most $1 *$ & 0.899916 & 477.0598 & 334.9837 & 0.0000 \\
\hline At most $2 *$ & 0.815847 & 366.5758 & 285.1425 & 0.0000 \\
\hline At most $3 *$ & 0.718649 & 285.3603 & 239.2354 & 0.0001 \\
\hline At most $4 *$ & 0.663283 & 224.4889 & 197.3709 & 0.0011 \\
\hline At most $5 *$ & 0.620339 & 172.2403 & 159.5297 & 0.0084 \\
\hline At most $6 *$ & 0.528097 & 125.7534 & 125.6154 & 0.0490 \\
\hline At most 7 & 0.380497 & 89.70630 & 95.75366 & 0.1212 \\
\hline At most 8 & 0.353616 & 66.72212 & 69.81889 & 0.0861 \\
\hline At most 9 & 0.267567 & 45.77680 & 47.85613 & 0.0774 \\
\hline At most $10^{*}$ & 0.249038 & 30.83042 & 29.79707 & 0.0379 \\
\hline At most $11 *$ & 0.190797 & 17.08323 & 15.49471 & 0.0286 \\
\hline At most $12 *$ & 0.134281 & 6.921351 & 3.841466 & 0.0085 \\
\hline
\end{tabular}

Note: the sign $(*)$ indicates an integrated equation and $(* *)$ indicates p-values 5 percent.

\section{VECM model estimation}

After obtaining the co-integration relationship between the twelve research variables, the next stage forms the VECM model. If there is a co-integration relationship between the research variables, then the estimation is done with VECM. VECM estimation results for short and long term can be seen in Table 3 and Table 4.

Table 3

Short-Term Influence

\begin{tabular}{lll}
\hline variable & coefficient & T Statistics \\
\hline CointEq1 & 2.6442 & 3.6089 \\
D (C. Mining (-1)) & -1.5875 & -1.0628 \\
D (C. Trading (-1)) & 22.4697 & 3.5095 \\
D (C. Construction (-1)) & 10.2973 & 2.2782 \\
D (C. Transportation (-1)) & -11.0412 & -3.0777 \\
D (C. Other (-1)) & 3.9304 & 0.4738 \\
D (NPL. Mining (-1)) & 0.3340 & 0.4535 \\
D (NPL. Trading (-1)) & 8.6686 & 3.3838 \\
D (NPL. Construction (-1)) & 1.3084 \\
D (NPL. Transportation (-1)) & 2.1074 & 2.4029 \\
D (NPL. Others (-1)) & 2.6601 & -1.6181 \\
D (Lending Facility (-1)) & -2.8648 & 3.1737 \\
F (Deposit (-1)) & 0.6961 & 1.0672 \\
F (NII (-1)) & 11.7700 & -4.1263 \\
\hline Not: itic & -0.8155 & \\
\hline
\end{tabular}

Note: italic print shows significant at a real rate of 5 percent. 
Based on Table 3, the estimation model for VECM is obtained in the short term as follows:

$$
\begin{aligned}
\Delta \mathrm{Y}_{\mathrm{t}}=-0,8155 \mathrm{D} & (\mathrm{Y}(-1))-1,5875 \mathrm{D}(\mathrm{X} 1(-1))+22,4697 \mathrm{D}(\mathrm{X} 2(-1))+10,2973 \mathrm{D}(\mathrm{X} 3(-1))-11,0412 \mathrm{D}(\mathrm{X} 4(-1)) \\
& +3,9304 \mathrm{D}(\mathrm{X} 5(-1))+0,3340 \mathrm{D}(\mathrm{X} 6(-1))+8,6686 \mathrm{D}(\mathrm{X} 7(-1))+2,1074 \mathrm{D}(\mathrm{X} 8(-1)) \\
& +2,6601 \mathrm{D}(\mathrm{X} 9(-1))-2,8648 \mathrm{D}(\mathrm{X} 10(-1))+0,6961 \mathrm{D}(\mathrm{X} 11(-1))+11,7700 \mathrm{D}(\mathrm{X} 12(-1)) \\
& +2,6442
\end{aligned}
$$

In the short-term variable credit and NPL trade large and retail, Construction Credit, Credit and NPL Transportation, warehousing and communication, Lending rate facility, and NII in the previous time had a significant effect on NII variables at the present time. While the variable credit and NPL mining and quarrying, Credit and other NPL, NPL Construction, and Deposit Collected is insignificant so it has no effect on NII.

The amount of large trade and retail credits positively affects NII by $22.4697 \%$ which means that every large trade and retail credit increases by $1 \%$, which will cause NII to increase by $22,469 \%$ in the short term.

Large and retail trade NPL has a positive influence on NII of $8.6686 \%$ which means that every large trade and retail NPL increases by $1 \%$, which will cause NII to increase by $8.6686 \%$ in the short term.

Construction Credit has a positive influence on NII of $10.2973 \%$ which means that each Construction Credit increases by $1 \%$, which will cause NII to increase by $10.2973 \%$ in the short term.

Transportation, warehousing, and communication loans negatively affect NII by $-11.0412 \%$ which means that every Transportation, warehousing, and communication Credit increases by $1 \%$, which will cause NII to decrease by $11.0412 \%$ in the short term.

NPL Transportation, warehousing and communication positively influenced NII by $2.6601 \%$ which means that every NPL of Transportation, warehousing and communication increased by $1 \%$, it will cause NII to increase by $2.6601 \%$ in the short term.

Lending rate Facility has a positive influence on NII of $0.6961 \%$ which means that each Lending Facility increases by $1 \%$, which will cause NII to increase by $0.6961 \%$ in the short term.

The above results are consistent with Dezfouli et al. (2014) they explained about one of the factors that npl that can erode profit if NPL increases.

The above results are also consistent with Borio et al. (2017) that there is a positive relationship between the lending rate facility structure and the bank's profitability. On the one hand, short-term interest rates and the tilt of the yield curve are positively linked to net interest income. But it's different from the results of Almazari (2014) which states that the Deposit affects NII but from the above research results for the short-term influence of Deposit to three commercial banks does not affect NII.

Table 4

Long-Term Influence

\begin{tabular}{lll}
\hline variable & coefficient & T Statistics \\
\hline D (C. Mining (-1)) & 1 & 1.2132 \\
D (C. Trading (-1)) & -10.8193 & -10.4398 \\
D (C. Construction (-1)) & 1.3744 & 1.7839 \\
D (C. Transportation (-1)) & 1.9409 & 3.6545 \\
D (C. other (-1)) & -6.9311 & -5.4452 \\
D (NPL. Mining (-1)) & -0.0913 & -0.9287 \\
D (NPL. Trading (-1)) & 1.6711 & 4.4113 \\
D (NPL. Construction (-1)) & 0.3389 & 1.8162 \\
D (NPL. Transportation (-1)) & 0.7609 & 4.7505 \\
D (NPL. Others (-1)) & -0.4254 & -1.2746 \\
D (Lending rate Facility (-1)) & -0.0057 & -0.1894 \\
D (Deposit) -1) & -10.6852 & -6.0887 \\
D (NII (-1)) & 0.1257 & 3.9195 \\
\hline Note italic print shows significant at a real rate of 5 percent & & \\
\hline
\end{tabular}

Note: italic print shows significant at a real rate of 5 percent.

In the long term it explains that credit variables and NPLs of large and retail trade, Transportation Credit and NPL, warehousing and communication, Other Loans, Deposit (Third Party Funds) are collected and NII has a significant impact on NII in the long run. In the long run the amount of large trade and retail loans negatively affects NII by $-10.8193 \%$ which means that every large trade and retail credit increases by $1 \%$, it will cause NII to decrease by $10.8193 \%$. 
Large trade and retail NPL positively influenced NII by $1.6711 \%$ which means that every large trade and retail NPL increases by $1 \%$, which will cause NII to increase by $1.6711 \%$ in the long run.

In the long run, the amount of Transportation Credit, warehousing and communication has a positive influence on NII of $1.9409 \%$ which means that every Transportation, warehousing, and communication Credit increases by $1 \%$, which will cause NII to increase by $1.9409 \%$.

In the long term NPL Transportation, warehousing and communication positively influenced NII by $0.7609 \%$ which means that every NPL of Transportation, warehousing and communication increased by $1 \%$, it will cause NII to increase by $0.7609 \%$.

In the long run, the amount of other loans negatively affects NII by $-6.9311 \%$ which means that every Other Credit increases by $1 \%$, it will cause NII to decrease by $6.9311 \%$.

In the long term, third party funds collected negatively affect NII by $-10.6852 \%$ which means that each Third-Party Fund collected has increased by $1 \%$, it will cause NII to decrease by $10.6852 \%$. There are differences with the results of Borio et al. (2017) which states there is a positive relationship between the structure of lending rate facility and bank profitability (NII) because this paper shows there is no significant relationship of lending rate with NII. On the contrary, the long-term influence of the Deposit has an influence on NII Consistent with the results of Almazari (2014).

Table 5

Short-Term Model Goodness Test

\begin{tabular}{lr} 
R-squared & 0.867455 \\
\hline Adj. & 0.811223
\end{tabular}

\begin{tabular}{lr} 
Adj. R-squared & 0.811223 \\
\hline
\end{tabular}

From the estimation model that has been obtained it is known that the value of goodness model is $\mathrm{R}^{2}$ Adjusted by $81.12 \%$ (Table 5). It can be interpreted that twelve independent variables can describe dependent variables by $81.12 \%$ and the remaining $18.88 \%$ described by other factors outside the model.

\section{Impulse response function (IRF)}

IRF analysis will explain the impact of shocks on one variable on other variables, which in this analysis is not only shortterm but can be analyzed for some time in the future as long-term information. In this study, the IRF test was conducted to show the NII response when the independent variable experienced shocks. The effect of shocks from the independent variables on NII can be measured from current events as well as events in the future. The IRF test also represents how long it takes for NII to return to its original state after one of the independent variables has experienced a drastic increase or decrease in value. IRF test results can be seen in Fig. 1 to Fig. 12.

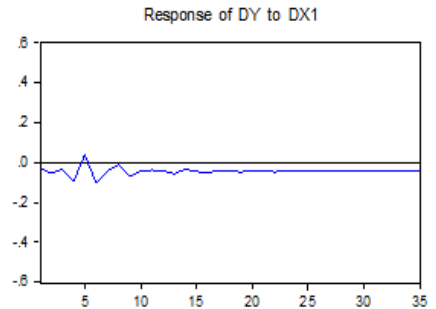

Fig. 1. Response of DY to DX1

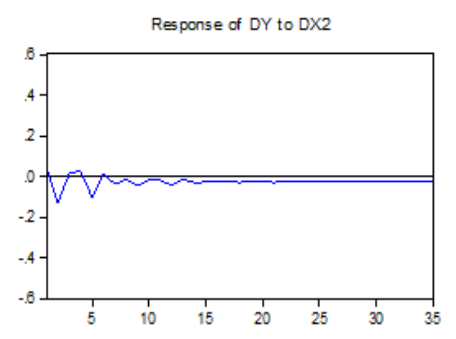

Fig. 2. Response of DY to DX2

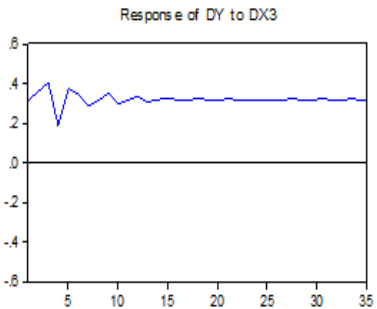

Fig. 3. Response of DY to DX3

Fig. 1 indicates that the response given by the variable NII (Y) due to a shock in the variable Number of mining and quarrying loans (X1) NII responded negatively from the beginning of the month. In the 5th month NII responded positively and reached its maximum point. The response achieved stability in the 18th period, which was -0.045326 percent of the initial value before the shock.

Fig. 2 shows that the response given by the variable NII (Y) due to a shock to the variable Amount of large trade and retail credits (X2), NII responded negatively from the 2nd month, the following month NII responded positively and began to reach the maximum in the 4th month. The response achieved stability in the 15 th period, which was -0.026798 percent of the initial value before the shock.

Fig. 3 shows that the response given by the NII variable (Y) due to a shock to the Construction Credit Amount (X3) variable NII responded positively. The response achieved stability in the 16 th period, amounting to 0.316957 percent of the initial value before the shock. 


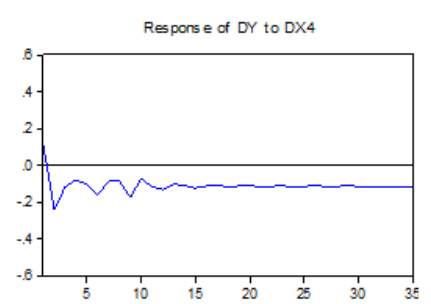

Fig. 4. Response of DY to DX4

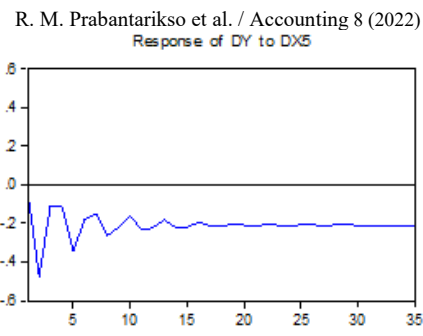

Fig. 5. Response of DY to DX5

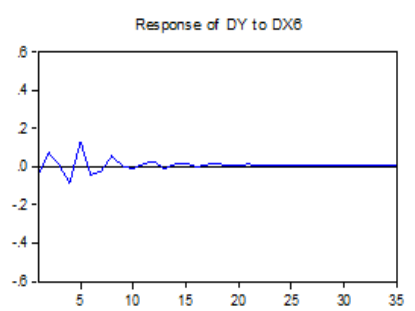

Fig. 6. Response of DY to DX6

Fig. 4 indicates that the response given by the variable NII (Y) due to the shock in the variable Amount of Transportation Credit, warehousing, and communication (X4). NII responds negatively from the 2nd month. The response achieved stability in the 19th period, which was -0.111099 percent of the initial value before the shock. Fig. 5 shows the response NII received was from a shock that occurred to the Number of Other Credits (X5) that nii responded negatively to. Starting from the 2 nd month the value is volatile until the 15 th month and begins to achieve stability in the 16 th month of -0.194698 percent. Fig. 6 describes NII's response to the shocks that occurred in the mining and quarrying NPL (X6) which were responded negatively from the beginning of the month by NII. However, nii response got a positive score in the 2 nd to 3 rd month. The NII response was volatile until the 18th month and reached a stability point in the 19th month of 0.005322 .

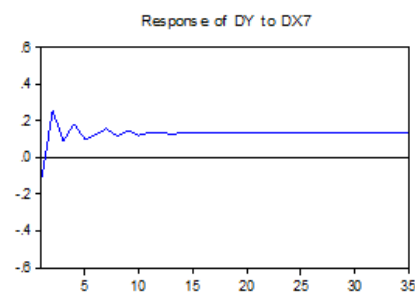

Fig. 7. Response of DY to DX4

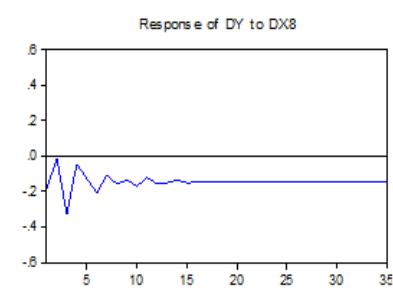

Fig. 8. Response of DY to DX5

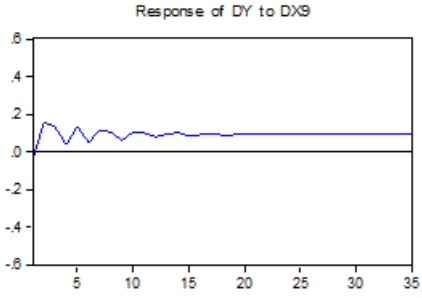

Fig. 9. Response of DY to DX6

In Fig. 7 NII's response to the shocks that occur in large trade and retail NPLs (X7) tends to be volatile because the response is positive starting in the 2 nd month and in the 2 nd month it is the maximum point achieved. The response achieved stability in the 14th period, which amounted to 0.136793 percent of the initial value before the shock.

In Fig. 8, respon subsequently received NII from the shock that occurred in NPL Construction (X8) which was responded negatively by NII. Starting from the 2 nd month the value is volatile until the 15 th month and reaches a minimum point in the 3rd month and reaches the start of stability in the 16th month of -0.146703 .

In Fig. 9, NII's response to shocks occurring in NPL Transportation, warehousing, and communication (X9) tends to be volatile. In the 2 nd month the NII response reached its maximum point. The response began to stabilize on the 16 th month of 0.093399 .

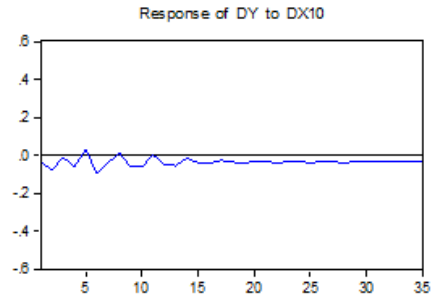

Fig. 10. Response of DY to DX4

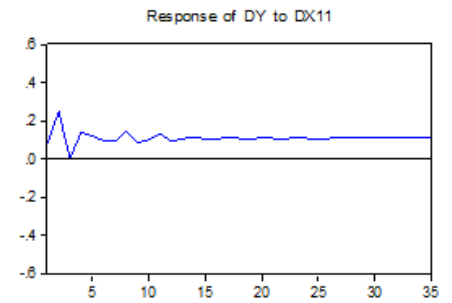

Fig. 11. Response of DY to DX5

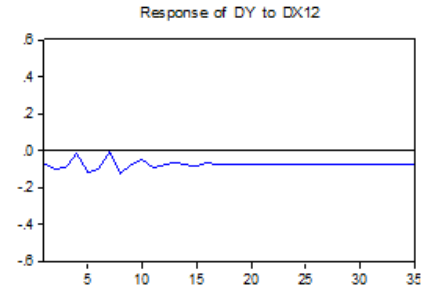

Fig. 12. Response of DY to DX6

Fig. 10 describes NII response to shocks that occurred in other NPL (X10) that were responded negatively from the beginning of the month by NII. However, the NII response received a positive score in the 5th month and the 8th month. Furthermore, the NII response was negative and reached a stability point in the 21 st month of -0.032898 .

Fig. 11 shows the NII response to the shock that occurred Lending rate Facility (X11). NII responds positively starting from the beginning of the month and reaching its maximum point in the 2 nd month. Then the response began to reach the point of stability in the 27 th month of 0.109898 .

In Fig. 12, response subsequently received by NII from the shock that occurred in the Deposit (X12) which was negatively responded by NII. Starting from the 2 nd month the value is volatile until the 19 th month and reaches the minimum point in the 8th month and begins to achieve stability in the 17 th month of -0.075729 . 
Variance decomposition aims to measure the magnitude of the contribution or composition of the influence of each independent variable on its dependent variables. Based on Fig. 13, the diversity began to appear in the first period. Construction credit variables contribute the most diversity to NII, followed next by other credit variables, npl construction and NPL trading. This indicates that future changes in NII will be influenced by the four variables that have the largest variety of contributions. The above results are consistent with Dezfouli et al. (2014) they explain the impact of NPL that can erode profit (NII) if NPL increases.

The above results are also consistent with Borio et al. (2017) that there is a positive relationship between the structure of the interest rate (lending rate facility) and bank profitability. On the one hand, short-term interest rates and the slope of the yield curve are positively related to net interest income. But it is different from the research results of Almazari (2014) which state that third party funds affect NII but from the research results above for the short-term effect of deposit, commercial banks do not affect NII.

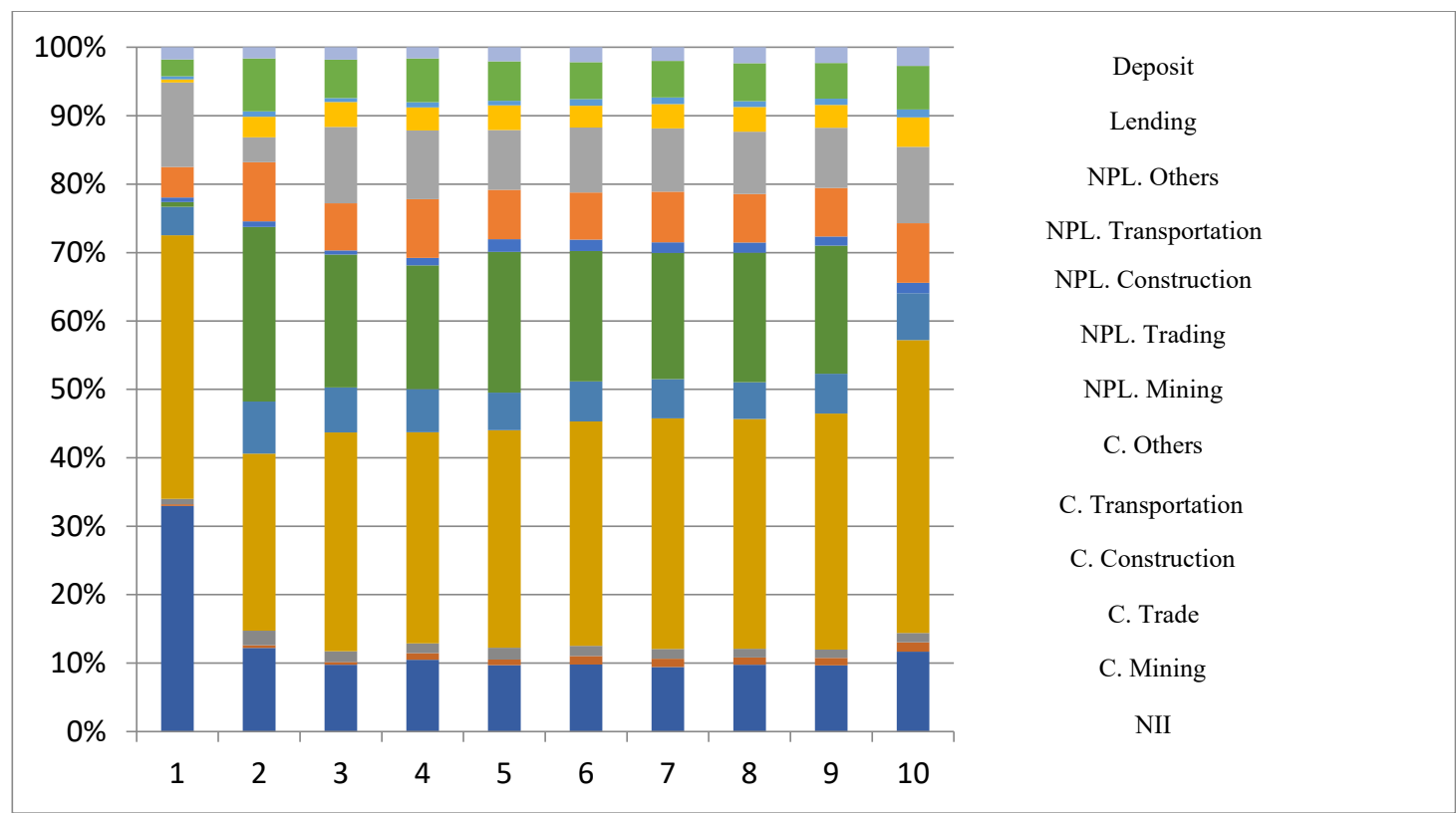

Fig. 13. Variance Decomposition of NII

Variance Decomposition analysis of NII variables in Fig. 13 above shows that the variable that contributes the most to NII for the next 10 periods is the Total Construction Credit with an average per period of $32,858 \%$, then variable Amount of Other Credit with an average per period of $17.78 \%$, variable NII with an average per period of $12.33 \%$, NPL Construction with an average per period of $9.168 \%$ and NPL. Trade with an average per period of $7.143 \%$.

\section{Conclusion}

Using Johansen's Cointegration Test, the cointegration test has shown that all variables in each short-term period tend to adjust to each other to achieve long-term balance. While in the short-term variable that affects NII is credit and NPL large trade and retail, Construction Credit, Credit and NPL Transportation, warehousing, and communication, as well as Lending rate Facility. While in the long term the variables that affect NII are variable credit and NPL large and retail trade, Credit and NPL Transportation, warehousing and communication, Other Credit and Deposit. The analysis of Impulse Response Function can be proven that NII most quickly achieves stability when dealing with the shocks of large trade and retail NPL. In the analysis of Forecasting Variance Decomposition, it can be concluded that the variable that contributes the most to NII is the number of credit constructions.

\section{Acknowledgments}

The authors would like to thank everyone who participated to complete this work, in particular the Rector of the Perbanas Institue and the Indonesian Banking School, for facilitating the publication in reputable international journals. 


\section{References}

Al-Tamimi, H. A. H. (2010). Factors Influencing Performance Of The Uae Islamic And Conventional National Banks. Global Journal of Business Research, 4(2), 1-9. https:/econpapers.repec.org/RePEc:ibf:gjbres:v:4:y:2010:i:2:p:1-9

Almazari, A. (2014). Impact of Internal Factors on Bank Profitability: Comparative Study Between Saudi Arabia and Jordan. Journal of Applied Finance \& Banking, 4(1), 1-7.

Bank of Indonesia. (2018). Indonesian Banking Statistics. Indonesian Banking Statistics, 17(1).

Bikker, J. A., \& Vervliet, T. M. (2018). Bank profitability and risk-taking under low interest rates. International Journal of Finance \& Economics, 23(1), 3-18. https://doi.org/https://doi.org/10.1002/ijfe.1595

Borio, C., Gambacorta, L., \& Hofmann, B. (2017). The influence of monetary policy on bank profitability. International Finance, 20(1), 48-63.

Dezfouli, M., Hasanzadeh, A., \& Shahchera, M. (2014). Inspecting the Effectiveness of Liquidity Risk on Banks Profitability. Kuwait Chapter of Arabian Journal of Business and Management Review, 3(9), 191-200.

Kohlscheen, E., Murcia Pabón, A., \& Contreras, J. (2018). Determinants of Bank Profitability in Emerging Markets (BIS Working Paper No. 686).

Kumar, V., Acharya, S., \& Ho, L. T. H. (2020). Does Monetary Policy Influence the Profitability of Banks in New Zealand? In International Journal of Financial Studies (Vol. 8, Issue 2). https://doi.org/10.3390/ijfs8020035

Kumaran, V. V., \& Ismail, M. (2018). An Empirical Analysis on Bank Profitability: Review on Macroeconomic Factors And Lending Rate. International Conference on Kaizen in Management, Education, Social Science And Technology (ICKMEST 2018).

Lamb, S. W. (2013). The Determinants of Community Bank's Profitability. Academy of Banking Studies Journal, 12(2).

Mukolu, M., \& Adeleke, K. (2020). Lending Rates and the Performance of Money Deposit Banks in Nigeria. International Journal of Management Studies and Social Science Research, 2(1), 124-131.

Prasanto, O., Wulandari, D., Narmaditya, B. S., \& Kamaludin, M. (2020). Determinants of Bank Profitability: A New Evidence from State-Owned Banks in Indonesia. Trikonomika. Trikonomika, 19(1), $29-35$. https://doi.org/10.23969/trikonomika.v19i1.1443

Syamni, G., \& Musnadi, Said Faisal, F. (2017). The Prime Lending Rate and Profitability of Regional Banks in Indonesia. Advanced Science Letters, 23(9), 8044-8046. https://doi.org/10.1166/asl.2017.9831

Tan, Y., \& Floros, C. (2012). Bank profitability and GDP growth in China: a note. Journal of Chinese Economic and Business Studies, 10(3), 267-273. https://doi.org/10.1080/14765284.2012.703541

Yüksel, S., Mukhtarov, S., Mammadov, E., \& Özsarı, M. (2018). Determinants of Profitability in the Banking Sector: An Analysis of Post-Soviet Countries. In Economies (Vol. 6, Issue 3). https://doi.org/10.3390/economies6030041

Zimmermann, K. (2017). Breaking Banks? Monetary Policy and Banks Profitability (pp. 1-36). University of Bonn. 
(C) 2022 by the authors; licensee Growing Science, Canada. This is an open access article distributed under the terms and conditions of the Creative Commons Attribution (CC-BY) license (http://creativecommons.org/licenses/by/4.0/). 